Review

\title{
Use of $\alpha$-Lactalbumin [ $\alpha$-La] from Whey as a Vehicle for Bioactive Compounds in Food Technology and Pharmaceutics: A Review
}

Andrea P. Cuevas-Gómez ${ }^{1,{ }^{\dagger}}$, Izlia J. Arroyo-Maya ${ }^{2,{ }^{+}}$, Humberto Hernández-Sánchez ${ }^{1,{ }^{+}, *}$

1. Depto. Ingeniería Bioquímica, Escuela Nacional de Ciencias Biológicas, Instituto Politécnico Nacional, Mexico City 07738, México; E-Mails: acuevasg1803@alumno.ipn.mx; hhernandezs@ipn.mx

2. Departamento de Procesos y Tecnología, Universidad Autónoma Metropolitana-Cuajimalpa, Mexico City 05348, México; E-Mail: iarroyo@correo.cua.uam.mx

$\dagger$ These authors contributed equally to this work.

* Correspondence: Humberto Hernández-Sánchez; E-Mail: hhernan1955@yahoo.com

Academic Editor: Victor Perez-Puyana, Alberto Romero and Mercedes Jiménez-Rosado

Special Issue: Characterization, Recovery and Valorization of Protein Concentrates from Residues and By-products of Agri-food Industry

Recent Progress in Materials

2021, volume 3, issue 2

doi:10.21926/rpm.2102027
Received: April 26, 2021

Accepted: June 08, 2021

Published: June 22, 2021

\begin{abstract}
Whey protein is a byproduct of cheese, casein, and Greek yogurt produced in Europe, North America, and Australasia. It is a substantial source of functional proteins and peptides for the worldwide food industry. $\alpha$-Lactalbumin ( $\alpha$-La) is a globular protein that can be isolated from WPI (whey protein isolates) using techniques such as chromatography/gel filtration, membrane separation, etc. $\alpha$-La is used in the elaboration of functional foods and is a very good source of peptides with anticancer, antimicrobial, antiviral, antihypertensive, immunomodulating, opioid, mineral-binding, and antioxidant bioactivities. Nanotubes and nanoparticles generated from this protein are utilized as vehicles for the transport of active compounds, and thus, can be used in foods and pharmaceutical industries. The contaminant
\end{abstract}

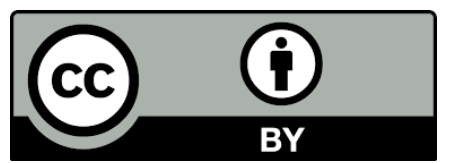

(C) 2021 by the author. This is an open access article distributed under the conditions of the Creative Commons by Attribution License, which permits unrestricted use, distribution, and reproduction in any medium or format, provided the original work is correctly cited. 
effects of whey, characteristics of $\alpha$-La, production technologies, and its applications in nanotechnology are reviewed here.

\section{Keywords}

Whey; $\alpha$-lactalbumin; bioactive compounds; encapsulation; nanotechnology

\section{Introduction}

Milk is one of the most important foods because of its high nutritional content. It is a good source of lipids, proteins, amino acids, vitamins, and minerals [1]. OECD/FAO [2] has reported an expansion of $1.4 \%$ in global milk production after a total of 880 million tons of milk was produced during 2020. Traditionally, the demand for milk is higher in urban centers, whereas the demand for fermented dairy products is superior in rural areas. Processed dairy products are becoming increasingly important in many countries, including the regions where animal protein demand is increasing faster than production.

OECD/FAO Agricultural Outlook reported the data of per capita consumption of processed and fresh dairy products in milk solids for different countries during the 2017-19 period (see Table 1) [2].

Table 1 Per capita consumption of processed and fresh dairy products in milk solids during 2017-2019 (kg/capita/year).

\begin{tabular}{lll}
\hline Country or Region & Fresh Dairy Products & Processed Dairy Products \\
\hline European Union & 11.2 & 15.8 \\
United States & 9.0 & 15.4 \\
India & 19.2 & 2.8 \\
Pakistan & 34.6 & 3.5 \\
China & 2.4 & 1.5 \\
Sub-Saharan Africa & 3.1 & 0.6 \\
World & 9.0 & 4.2 \\
\hline
\end{tabular}

The world milk production is anticipated to grow at $1.6 \%$ per year (to $997 \mathrm{Mt}$ by 2029) over the next decade, and this is faster than the rate of most other agricultural goods [2]. The maximum amount of milk is consumed in the form of fresh dairy products, including pasteurized and fermented products. Greek yogurt is a very popular fermented dairy food. However, its production generates large amounts of acid whey as a byproduct (one liter of milk used to produce Greek yogurt generates $666 \mathrm{~mL}$ of acid whey). The post-processing treatment of this primary waste stream is one of the main concerns for the dairy industry $[3,4]$.

The byproduct from the elaboration of hard and semi-hard cheeses is known as sweet whey and has a $\mathrm{pH}$ between 5.9 and 6.6. Fresh acid-curd cheeses such as quarg, cottage, cream, fromage frais, and ricotta are the products obtained by the coagulation of milk, cream, or whey via acidification or a combination of acid and heat [5]. The manufacture of quarg, cottage, and cream cheeses and Greek yogurt yields acid whey with a pH between 4.3 and 4.6. The approximate composition of whey 
includes water (94-95\%), lactose (3.8-4.2\%), proteins (0.8-1\%), minerals (0.7-0.8\%), and fat (0.05\%) [6]. Whey proteins are mainly globular proteins that are highly soluble and heat-labile. Alphalactalbumin ( $\alpha-\mathrm{La})$ and beta-lactoglobulin $(\beta-\mathrm{Lg})$ are the most abundant components constituting approximately $20-25 \%$ and $50-55 \%$ of the whey proteins, respectively. They are responsible for the functional properties of whey, such as foaming, emulsion, and gel formation $[7,8]$.

In recent years, whey has been widely used as a bioactive ingredient for healthy tailored dairy beverages. These beverages are mostly associated with fruits or other functional ingredients possessing prebiotic properties or fermented with probiotic bifidobacteria and lactic acid bacteria [9].

Whey must be processed as soon as possible after its production to avoid the growth of bacteria responsible for protein degradation and lactic acid formation. Whey proteins can easily be recovered by different methods. The whey proteins obtained by ultrafiltration or ion exchange have good functional properties and can be highly nutritional, as in the case of whey protein isolates (WPI). Whey proteins have also been used for the prevention and treatment of abdominal obesity [10]. The most common techniques used for the membrane filtration of dairy products are microfiltration (MF), ultrafiltration (UF), and reverse osmosis (RO). These technologies differ in terms of particle size, molecular weight, and the components that they separate [11-13].

Whey protein concentrates are produced from the skim milk permeate in the MF process. They can be further concentrated through UF using diafiltration, ion exchange, or electrodialysis to remove the salts and the remaining lactose to produce WPI with up to $90 \%$ of protein content [14, 15]. The contaminant effects of whey, characteristics of $\alpha$-La, production technologies, and its applications in nanotechnology are reviewed here.

\section{Contaminant Effect of Whey Remnant}

All types of milk, cream, and most other dairy products and byproducts have a very high oxygen demand, and their release into the environmental water sources causes serious pollution. This can happen because of spills, process leaks, overfilled containers, containment failures, wrong drainage connections, and blocked drains. Biological Oxygen Demand (BOD) represents the amount of oxygen consumed by microorganisms while they decompose organic matter under aerobic conditions at a specific temperature. The BOD of whey is between 20,000 and $50,000 \mathrm{mg}$ of $\mathrm{O}_{2} / \mathrm{L}$ [16]. This value is around 100 times higher than that of domestic sewage (400 $\mathrm{mg}$ of $\mathrm{O}_{2} / \mathrm{L}$ ). Therefore, the necessity to treat and use these dairy effluents is essential.

On the other hand, Chemical Oxygen Demand (COD) is defined as the number of oxygen equivalents consumed in the chemical oxidation of organic matter by a strong chemical oxidant [17]. Natural Resources Wales [18] and Bylund [12] have reported the COD and BOD of the main dairy products (see Table 2). The waste load equivalents of specific milk constituents are $1 \mathrm{~kg}$ of milk fat $=3 \mathrm{~kg} \mathrm{COD} ; 1 \mathrm{~kg}$ of lactose $=1.13 \mathrm{~kg}$ COD; and $1 \mathrm{~kg}$ of protein $=1.36 \mathrm{~kg}$ COD [19]. Whey protein is a very valuable component that can be utilized in the manufacture of many food products, and hence, prevent its wastage as an environmental pollutant.

Table 2 COD and BOD of the main dairy products.

\begin{tabular}{lll}
\hline Dairy product & COD $(\mathrm{mg} / \mathrm{L})$ & BOD $(\mathrm{mg} / \mathrm{L})$ \\
\hline Whole milk & 220000 & 120000 \\
\hline
\end{tabular}




\begin{tabular}{lll}
\hline Skim milk & 105000 & 70000 \\
Raw whey & 82000 & 40000 \\
\hline
\end{tabular}

\section{3. $\alpha$-Lactalbumin}

$\alpha$-La is a globular protein (123 amino acids, $14.2 \mathrm{kDa}$ ) with one calcium-binding site, four disulfide bonds, and an isoelectric point between 4.2-4.6 [20]. It is one of the two components of the enzyme lactose synthase, which catalyzes the final step in lactose biosynthesis in the lactating mammary gland [20]. It is a protein that regulates the production of lactose in the milk of most mammalian species. This protein provides vital essential amino acids such as tryptophan, lysine, and cysteine, and therefore, is important for the rapidly growing neonate [21-24].

$\alpha$-La is attractive because of its physical characteristics like a clean flavor profile, high water solubility, and relative heat stability (which, when combined, allow for diverse food applications). Some biological properties derived from its structure are also important. This includes the capacity of $\alpha$-La to form a complex with oleic acid at low $\mathrm{pH}$ values and render anticancer properties (BAMLET) $[25,26]$.

The use of $\alpha$-La in infant and standard (whole protein) formulas has been limited due to its allergenic potential. It causes about $30-35 \%$ of the IgE-mediated cow's milk allergy [27]. This problem can be reduced if enzymatic digestion is used before incorporating the protein into foods. Several peptides released from $\alpha$-La during digestion have been shown to elicit biological effects such as antitumor, antibacterial, antihypertensive, immunomodulatory, opioid, mineral-binding, and antioxidative activities [15]. It has also been reported that some of the peptides formed during hydrolysis by trypsin, chymotrypsin, or pepsin might possess specific activity against herpes simplex and HIV-1 virus [28].

Some researchers have reported the binding between $\alpha$-La and three fat-soluble vitamins $\left(A, D_{3}\right.$, and E). However, this protein has also been shown to effectively bind other hydrophobic bioactive compounds such as retinol, genistein, kaempferol, curcumin, EGCG (epigallocatechin gallate), capsaicin, and trans-resveratrol in high-affinity pockets for transportation inside the body [29-31]. It is well known that protein-based micro-and nanoparticles are suitable for use as carriers for bioactive compounds found in foods such as peptides, vitamins, functional lipids, and antioxidants [32].

The functionality of $\alpha$-La has been studied in terms of its emulsifying, gelling, and foaming properties [33, 34] that allow its use in different areas like food additives, nutritional or pharmaceutical applications, and protein-fortified beverages. A combination of various emergent technologies has permitted the preparation of $\alpha$-La in significant amounts with different purity levels (up to 87\%) and allowed its use as an important nutrient and ingredient of functional foods [5].

\section{Methods to Obtain $\alpha$-Lactalbumin}

Different methods have been used to isolate whey protein: affinity chromatography, membrane filtration (including MF, UF), size-exclusion chromatography, ion exchange, and variations in $\mathrm{pH}$, etc. Membrane filtration is the main method used for the isolation of this protein [35].

The fractionation of a protein mixture with an ultrafiltration membrane is not easy since the sizes and $\mathrm{MW}$ of the proteins are close together [36]. Isolation and purification of $\alpha$-La from whey can be 
achieved using different methods. The method reported by Heine, Klein, and Miyashita [37] involved the extraction of $\alpha$-La from acidified, heat-treated whey using an organic solvent. The $\alpha$-La was then precipitated from the solvent using a base.

Lucas et al. [36] extracted $\alpha$-La from acid casein WPC at pH 7 by limiting the $\beta$-Lg transmission with inorganic membranes that were chemically modified by a polyethyleneimine coating carrying positive charges.

Both proteins ( $\alpha$-La and $\beta$-Lg) have close molecular weights (14.2 and $18.6 \mathrm{kDa}$, respectively). Hence, their direct fractionation using conventional industrial technologies such as membrane filtration is difficult [38]. However, recent technologies such as microfiltration and ultrafiltration at high shear rates and aqueous two-phase extraction can be applied to isolate whey proteins in lesser time and obtain better results in their purification [39, 40]. Muller et al. [41] proposed a prepurification of $\alpha$-La by UF of acid casein whey with the limited transmission of $\beta$-Lg. Ultrafiltration steps were carried out with mineral membranes that increased the purity of $\alpha$-La in the filtrate and also retained the bovine serum albumin and immunoglobulin fractions. Ben Ounis et al. [42] reported the elimination of minor protein components from whey protein isolates by heparin affinity chromatography.

\section{5. $\alpha$-Lactalbumin in Nanotechnology}

Nanotechnological methods are designed to produce materials of various types at the nanoscale level. This field is used in different areas like pharmacy, medicine, engineering, materials, and foods. Food nanotechnology has been used as a new tool for pathogen detection, disease prevention, food packaging, and delivery of bioactive compounds to target sites [43]. Nanoparticles and nanotubes are the most common shapes obtained in the case of $\alpha$-La [44]. The amino acid composition of $\alpha$-La is one of the factors responsible for its solubility, viscosity, emulsification, foaming, and protein nanoparticle formation, similar to that of other albumins [45].

Partial hydrolysis of bovine $\alpha$-La with Bacillus licheniformis protease (BLP) induces the formation of nanotubular structures with an average diameter of $20 \mathrm{~nm}$ and a cavity of about $8 \mathrm{~nm}$, in the presence of calcium ions by a self-assembly process. The presence of this cavity enables the $\alpha$-La nanotubes to function as vehicles for encapsulating molecules such as vitamins, bioactive compounds, colorants, and enzymes. Fuciños et al. [46] encapsulated caffeine at high efficiency using $\alpha$-La-based nanotubes. Additionally, the growth of nanotubes induces the formation of stiff transparent protein gels due to the well-arranged networks formed by the strands. These gels can be used for the entrapment, transportation, and delivery of colorants and bioactive compounds in the food and pharmaceutical industries [47].

Nanoparticles (NPs) are a wide class of materials that include particulate substances, which have at least one dimension less than $100 \mathrm{~nm}$ [48]. WPI nanoparticles (NPs) have been prepared by the desolvation process using ethanol as the anti-solvent. The size of the WPI nanoparticles ranged between 10 and $100 \mathrm{~nm}$ and they possessed the potential to stabilize emulsions [49]. WPI NPs have also been used to encapsulate 3,3'-diindolylmethane, a bioactive compound found in cruciferous vegetables with antioxidant, anticancer, and anti-inflammatory properties [50].

In another study, Arroyo-Maya et al. [51] reported spheroidal nanoparticles prepared from bovine $\alpha$-La cross-linked with glutaraldehyde in the presence of acetone. The NPs had sizes between 100 and $160 \mathrm{~nm}$, and their morphology, as determined by transmission electron microscopy (TEM), 
is shown in Figure 1. These nanostructures displayed excellent pH stability. Further, the overall structure and size of $\alpha$-LA NPs underwent only minor changes within the $\mathrm{pH}$ interval of $3.0-9.0$ at $25^{\circ} \mathrm{C}$.

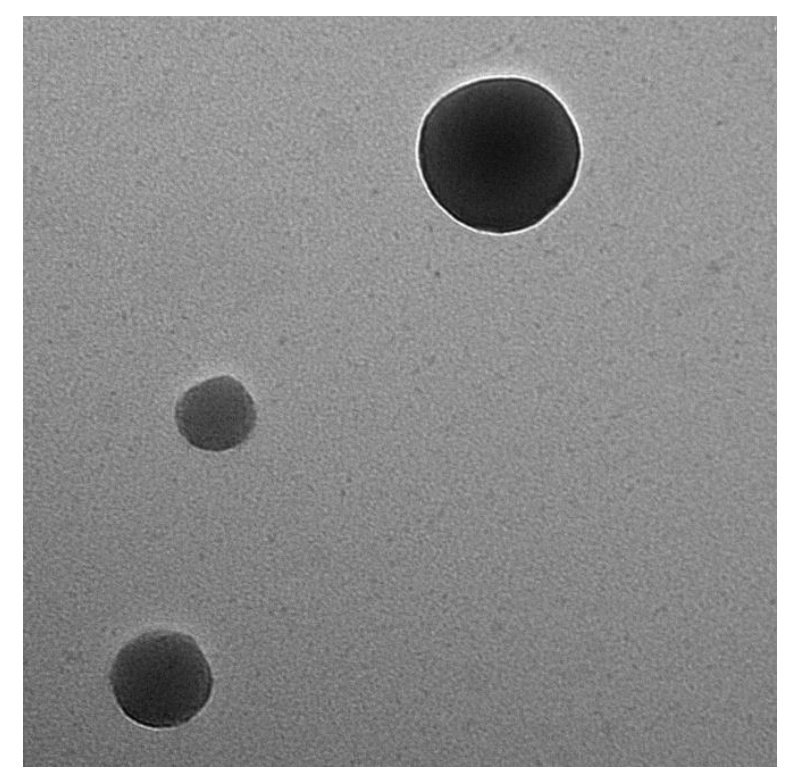

Figure 1 Morphology and size of $\alpha$-La nanoparticles obtained by the desolvation method with acetone as observed by TEM. Magnification 100,000 X (adapted from [50]).

Thus, this variety of architecture renders $\alpha$-La a potential vehicle for the introduction of challenging lipophilic compounds such as capsaicin (CAP) into foods and beverages. The low solubility of capsaicin otherwise makes this molecule hard to introduce in foods other than high-fat foods. [31].

Carvalho et al. [52] reported a high efficiency ( $>45 \%$ ) process for riboflavin nanoencapsulation in $\alpha$-La NPs. The system presented instability only after 120 days, a period, which is acceptable for applications in food technology. There are only a few reports on riboflavin nanoencapsulation, and their entrapment efficiencies are also around 45\% [53, 54]. $\alpha$-La NPs have also been used for the controlled release of methotrexate, an antimetabolite of the antifolate type, used in the treatment of cancer and rheumatoid arthritis [55]. The above information confirms the fact that $\alpha$-La and milk proteins, in general, are excellent encapsulation devices and delivery vehicles for bioactive compounds for foods and pharmaceutics due to their structural and physicochemical properties [56, 57].

\section{Concluding Remarks}

$\alpha$-La has many potential applications in food technology, pharmaceutics, and nanotechnology. It has been used as a wall material for nanoparticles, as a vehicle for bioactive compounds, and as a substrate for the generation of bioactive peptides. In the case of WPI and $\alpha$-La nanoparticles, their stability at different $\mathrm{pH}$ values, their size dependence on the preparation conditions, and their safety make them an attractive wall material for the encapsulation of bioactive compounds in the development of functional food products. This can generate benefits for human health. Current 
investigations include the generation of nanoparticles with different purposes and specific action sites.

\section{Author Contributions}

A.P.C.G, I.J.A.M and H.H.S conceived the idea, A.P.C.G performed the review of the literature, A.P.C.G, I.J.A.M and H.H.S analyzed the data and A.P.C.G and H.H.S wrote the paper.

\section{Competing Interests}

The authors declare that no competing interests exist.

\section{References}

1. Haug A, Hostmark AT, Harstad OM. Bovine milk in human nutrition - a review. Lipids Health Dis. 2007; 6: 1-16.

2. OECD/FAO. OECD-FAO agricultural outlook 2020-2029. Paris: OECD Publishing; 2020.

3. Xu JJ, Hao JX, Guzman JJ, Spirito CM, Harroff LA, Angenent LT. Temperature-phased conversion of acid whey waste into medium-chain carboxylic acids via lactic acid: No external e-donor. Joule. 2018; 2: 280-295.

4. Uduwerella G, Chandrapala J, Vasiljevic T. Minimising generation of acid whey during Greek yoghurt manufacturing. J Dairy Res. 2017; 84: 346-354.

5. Guinee TP, Pudja PD, Farkye NY. Fresh acid-curd cheese varieties. In: Cheese: Chemistry, physics and microbiology. Boston: Springer; 1993.

6. Severino Vasconcelos QD, Rodrigues Bachur TP, Frota Aragão G. Whey Protein: Composition, use and benefits - a narrative review. Eur J Phys Educ Sport Sci. 2018; 4: 173-183.

7. Walzem RL, Dillard CJ, German JB. Whey components: Millennia of evolution create functionalities for mammalian nutrition: What we know and what we may be overlooking. Crit Rev Food Sci Nutr. 2002; 42: 353-375.

8. Aimutis WR. Bioactive properties of milk proteins with particular focus on anticariogenesis. J Nutr. 2004; 134: 989S-995S.

9. Henriquez $M$, Gomez D, Borges A, Pereira C. Liquid whey protein concentrates as primary raw material for acid dairy gels. Food Sci Technol. 2020; 40: 361-369.

10. Pal S, McKay J, Jane M, Ho S. Dairy whey proteins and obesity. In: Nutrition in the prevention and treatment of abdominal obesity. San Diego: Academic Press; 2019.

11. Daufin G, Escudier JP, Carrere H, Berot S, Fillaudeau L, Decloux M. Recent and emerging application of membrane processes in the food and dairy industry. Food Bioprod Process. 2001; 79: 89-102.

12. Tetra Pak. Dairy Processing Handbook. Lund, Sweden: Tetra Pak Processing Systems AB; 2015.

13. Pouliot T. Membrane processes in dairy technology - from a simple idea to worldwide panacea. Int Dairy J. 2008; 18: 735-740.

14. Carter BG, Drake MA. Invited review: The effects of processing parameters on the flavor of whey protein ingredients. J Dairy Sci. 2018; 101: 6691-6702.

15. Kamau SM, Cheison SC, Chen W, Liu XM, Lu RR. Alpha-lactalbumin: Its production technologies and bioactive peptides. Compr Rev Food Sci F. 2010; 9: 197-212. 
16. Valencia E, Ramírez ML. La industria de la leche y la contaminación del agua. Elementos. 2009; 73: 27-31.

17. Jain SK, Singh VP. Water Quality Modeling. In: Developments in water science. Water resources systems planning and management. Amsterdam: Elsevier; 2003.

18. Dairy and milk processing sector. Cardiff: Natural Resources Wales; 2014.

19. Kumar D, Desai K, Gupta D. Pollution abatement in milk dairy industry. J Curr Pharma Res. 2011; 1: 145-152.

20. Permyakov EA. $\alpha$-Lactalbumin. New York: Nova Science; 2005.

21. Joubran Y, Moscovici A, Portmann R, Lesmes U. Implications of the Maillard reaction on bovine alpha-lactalbumin and its proteolysis during in vitro infant digestion. Food Funct. 2017; 8: 22952308.

22. Lönnerdal B. Infant formula and infant nutrition: Bioactive proteins of human milk and implications for composition of infant formulas. Am J Clin Nutr. 2014; 99: 712S-717S.

23. Roncada P, Piras C, Soggiu A, Turk R, Urbani A, Bonizzi L. Farm animal milk proteomics. J Proteom. 2012; 75: 4259-4274.

24. Sandström O, Lönnerdal Bo, Graverholt G, Hernell O. Effects of alpha-lactalbumin-enriched formula containing different concentrations of glycomacropeptide on infant nutrition. Am J Clin Nutr. 2008; 87: 921-928.

25. Layman DK, Lönnerdal B, Fernstrom JD. Applications for $\alpha$-lactalbumin in human nutrition. Nutr Rev. 2018; 76: 444-460.

26. Svensson M, Håkansson A, Mossberg AK, Linse S, Svanborg C. Conversion of alpha-lactalbumin to a protein inducing apoptosis. Proc Natl Acad Sci USA. 2000; 97: 4221-4226.

27. Qasba PK, Kumar S, Brew K. Molecular divergence of lysozymes and $\alpha$-lactalbumin. Crit Rev Biochem Mol Biol. 1997; 32: 255-306.

28. Jakopović KL, Barukčić I, Božanić R. Physiological significance, structure, and isolation of $\alpha$ lactalbumin. Mljekarstvo. 2016; 66: 1-13.

29. Delavari B, Saboury AA, Atric MS, Ghasemia A, Bigdeli B, Khammari A, et al. Alpha-lactalbumin: A new carrier for vitamin D3 food enrichment. Food Hydrocol. 2015; 45: 124-131.

30. Mohammadi F, Moeeni M. Analysis of binding interaction of genistein and kaempferol with bovine $\alpha$-lactalbumin. J Funct Food. 2015; 12: 458-467.

31. Romano A, Lajterer C, Shpigelman A, Lesmes U. Bovine alpha-lactalbumin assemblies with capsaicin: Formation, interactions, loading and physiochemical characterization. Food Chem. 2021; 352: 129306.

32. Chen L, Remondetto GE, Subirade M. Food protein-based materials as nutraceutical delivery systems. Trends Food Sci Technol. 2006; 17: 272-283.

33. Lajnaf R, Picart-Palmade L, Attia H, Marchesseau S, Ayadi MA. Foaming and adsorption behavior of bovine and camel proteins mixed layers at the air/water interface. Colloid Surface B. 2017; 151: 287-294.

34. Matsudomi N, Oshita T, Kobayashi K, Kinsella JE. Alpha-lactalbumin enhances the gelation properties of bovine serum albumin. J Agric Food Chem. 1993; 41: 1053-1057.

35. Zydney AL. Protein separations using membrane filtration: New opportunities for whey fractionation. Int Dairy J. 1998; 8: 243-250.

36. Lucas D, Rabiller-Baudry M, Millesime L, Chaufer B, Daufin G. Extraction of $\alpha$-lactalbumin from whey protein concentrate with modified inorganic membranes. J Membr Sci. 1998; 148: 1-12. 
37. Heine $\mathrm{W}$, Klein $\mathrm{P}$, Miyashita $\mathrm{C}$. Method for isolating alpha-lactalbumin from whey [Internet]. French Patent No. WO 92/03468; 1991. Available from: https://www.freepatentsonline.com/W01992003468.pdf.

38. El-Sayed MM, Chase HA. Trends in whey protein fractionation. Biotechnol Lett. 2011; 33: 15011511.

39. Espina V, Jaffrin MY, Ding L. Extraction and separation of $\alpha$-lactalbumin and $\beta$-lactoglobulin from skim milk by microfiltration and ultrafiltration at high shear rates: A feasibility study. Sep Sci Technol. 2009; 44: 3832-3853.

40. Domínguez-Puerto R, Valle-Guadarrama S, GuerraRamírez D, Hahn-Schlam F. Purification and concentration of cheese whey proteins through aqueous two-phase extraction. CYTA J Food. 2018; 16: 452-459.

41. Muller A, Chaufer B, Merin U, Daufin G. Prepurification of $\alpha$-lactalbumin with ultrafiltration ceramic membranes from acid casein whey: Study of operating conditions. Dairy Sci Technol. 2003; 83: 111-129.

42. Ben Ounis W, Gauthier SF, Turgeon SL, Roufik S, Pouliot Y. Separation of minor protein components from whey protein isolates by heparin affinity chromatography. Int Dairy J. 2008; 18: 1043-1050.

43. Ladan R, Khosravi-Darani K. The applications of nanotechnology in food industry. Crit Rev Food Sci Nutr. 2011; 51: 723-730.

44. Katouzian I, Jafari SM. 4-Nanotubes of $\alpha$-lactalbumin for encapsulation of food ingredients. In: Biopolymer nanostructures for food encapsulation purposes. London: Academic Press; 2019.

45. Arroyo-Maya IJ, Rodiles-López JO, Cornejo-Mazón M, Gutiérrez-López GF, Hernández-Arana A, Toledo-Núñez $C$, et al. Effect of different treatments on the ability of $\alpha$-lactalbumin to form nanoparticles. J Dairy Sci. 2012; 95: 6204-6214.

46. Fuciños C, Míguez $M$, Fuciños $P$, Pastran LM, Rúa ML, Vicente AA. Creating functional nanostructures: Encapsulation of caffeine into $\alpha$-lactalbumin nanotubes. Innov Food Sci Emerg. 2017; 40: 10-17.

47. Tarhan Ö, Hamaker BR, Campanella OH. Structure and binding ability of self-assembled $\alpha$ lactalbumin protein nanotubular gels. Biotechnol Prog. 2021: e3127. Doi: 10.1002/btpr.3127.

48. Laurent S, Forge D, Port M, Roch A, Robic C, Vander L, et al. Magnetic iron oxide nanoparticles: Synthesis, stabilization, vectorization, physicochemical characterizations, and biological applications. Chem Rev. 2008; 108: 2064-2110.

49. Gülseren I, Fang Y, Corredig M. Whey protein nanoparticles prepared with desolvation with ethanol: Characterization, thermal stability, and interfacial behavior. Food Hydrocol. 2012; 29: 258-264.

50. Khan A, Wang CN, Sun XM, Killpartrick A, Guo MR. Preparation and characterization of whey protein isolate-DIM nanoparticles. Int J Molec Sci. 2019; 20: 3917.

51. Arroyo-Maya IJ, Hernández-Sánchez $\mathrm{H}$, Jiménez-Cruz E, Camarillo-Cadena $M$, Hernández-Arana A. $\alpha$-Lactalbumin nanoparticles prepared by desolvation and cross-linking: Structure and stability of the assembled protein. Biophys Chem. 2014; 193-194: 27-34.

52. Carvalho R, Fonseca G, Coimbra J, Mageste A, Santos I. Encapsulação de vitamina B2 em nanoestruturas de $\alpha$-lactoalbumina. Proceedings of the Anais do XII Congresso Brasileiro de Engenharia Química em Iniciação Científica; 2017 July; São Carlos, Brasil. 
53. Morrison PW, Connon CJ, Khutoryanskiy VV. Cyclodextrin-mediated enhancement of riboflavin solubility and corneal permeability. Mol Pharmaceutics. 2013; 10: 756-762.

54. Diarrassouba F, Liang L, Remondetto G, Muriel Subirade. Nanocomplex formation between riboflavin and $\beta$-lactoglobulin: Spectroscopic investigation and biological characterization. Food Res Int. 2013; 52: 557-567.

55. Vijayaragavan S, Jayaraman G. Controlled release of methotrexate using alpha-lactalbumin nanoparticles. Lat Am J Pharm. 2014; 33: 171-175.

56. Livney YD. Milk proteins as vehicles for bioactives. Curr Opin Colloid Interface Sci. 2010; 15: 7383.

57. Tavares GM, Croguennec T, Carvalho AF, Bouhallab S. Milk proteins as encapsulation devices and delivery vehicles: Applications and trends. Trends Food Sci Technol. 2014; 37: 5-20.

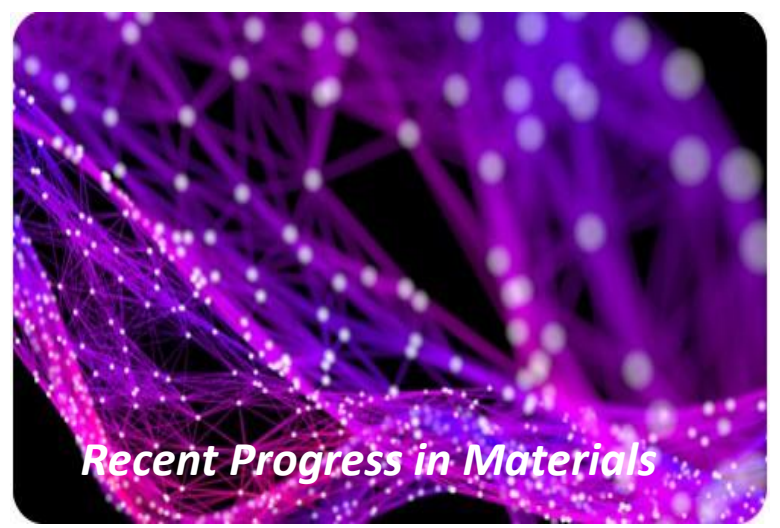

Enjoy Recent Progress in Materials by:

1. Submitting a manuscript

2. Joining in volunteer reviewer bank

3. Joining Editorial Board

4. Guest editing a special issue

For more details, please visit:

http://www.lidsen.com/journals/rpm 